\section{Global Proceedings Repository \\ American Research Foundation}

ISSN 2476-017X

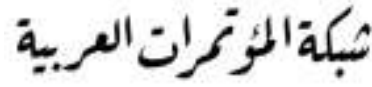

http://arab.kmshare.net/

Available online at http://proceedings.sriweb.org

The Ninth International Scientific Academic Conference

Under the Title "Contemporary trends in social, human, and natural sciences"

$$
\begin{aligned}
& \text { المؤتمر العلمي الاكاديمي الدولي التاسع - (لمع } \\
& \text { تحت عنوان "الاتحاهات المعاصرة في العلوم الاجتماعية، الانسانية، والطبيعية" } \\
& 17 \text { - } 18 \text { يوليو - تموز } 2018 \text { - اسطنبول - تركيا }
\end{aligned}
$$

http://kmshare.net/isac2018/

\title{
Resilience of Vulnerable Internally Displaced Persons between Humanitarian Food Security Assistance and Sustainable Social Development Programmes in West Darfur
}

\author{
Dr. Nagwa Babiker Abdalla Yousif \\ Department of Sociology and Social Work, College of Mass Communication and Humanities, \\ Ajman University, UAE; Correspondence E-mail: nagwabfatima@gmail.com
}

\begin{abstract}
The Departments of West Darfur State Government, national civil society organizations, and international voluntary action organizations provide humanitarian assistance to internally displaced persons (IDPs) in Geneina and Habila in West Darfur, Sudan. According to the 2008 Sudan census, the population of IDPs was estimated at 1.6 million due to civil war, drought, and desertification in the region. Throughout this paper, the term 'old' IDPs will be used to refer to people whose age is $60+$ years. The main objectives of the study was to identify the degree to which vulnerable 'old' IDPs rely on humanitarian food security assistance and sustainable development programmes in West Darfur (Geneina and Habila). Other objectives included to gain knowledge of the socio-economic characteristics of 'old' IDPs and their families, to explore
\end{abstract}




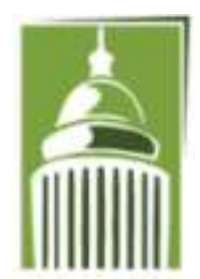

ARF

\section{Global Proceedings Repository \\ American Research Foundation}

ISSN 2476-017X

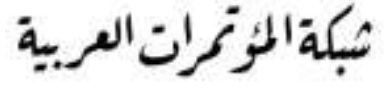

http://arab.kmshare.net/

Available online at http://proceedings.sriweb.org

food insecurity causes and the food security strategies adapted by the 'old' IDPs in the two camps of Geneina and Habila, to increase our understanding of the socio-economic conditions of the IDP old people (60+ years) at the Geneina and Habila camps in terms of income, land and animal ownership systems, and the social protection system and to identify social development services and facilities related to water, health, education and social insurance. These objective are achieved by using a questionnaire approved by the Humanitarian Aid Commission, as well using the qualitative analysis by adopting the focus group discussions, and a review and analysis of secondary data. The questionnaire was administered in 2017 in urban Geneina and rural Habila. Simple random sampling was used to select 220 IDPs: 117 women and 103 men.

The Statistical Packages for the Social Sciences ( SPSS), was used to analyse the collected data and these are some of the study results with using Chi-Square test independent of the factors contributing to Low productivity and area, the study found that there is no relationship between the two factors, and the same result for the factors of food shortage coping strategies and the IDP age, while using the same test a relationship has been found between the factors of preventing from raising animals and the camp location area

Keywords: Internally Displaced Peoples, humanitarian assistance, social development, food insecurity 


\section{Global Proceedings Repository \\ American Research Foundation}

ISSN 2476-017X

Available online at http://proceedings.sriweb.org

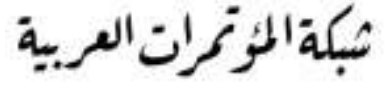

http://arab.kmshare.net/

ARF

\section{Introduction}

Darfur is situated in the westernmost part of Sudan, stretching along the frontier between the Sahara desert and tropical Africa, and borders the Republic of Central Africa, Chad, and Libya. The region is comprised of North, West and South Darfur, and as of 2012, East and Central Darfur East and Central Darfur. The population of Darfur is rapidly growing, and internally displaced persons (IDPs) account for 1.66 million of the greater Darfur population and $20.9 \%$ of the total regional population (Central Bureau of Statistics Sudan, 2008). The 2009 report from the United Nations Office for the Coordination of Humanitarian Affairs (OCHA) stated that the total number of IDPs in West Darfur was estimated to be 746,912 .

\section{Problem Statement}

Tribal and civil conflicts, as well as climate change, were largely responsible for the IDP phenomena in West Darfur that negatively impacted food security among IDPs. Over time, factors such as increasing food consumption, inflation, and a consequent weakened economic situation, have also contributed significantly to food insecurity among IDPs. Specifically, food security deteriorated among 'old' IDPs in West Darfur in 2016 due to reduced economic resources, disproportionally high commodity prices, and an increase in transportation costs and taxes. This situation forced IDPs to return to their homes to cultivate crops. The 2017 Humanitarian Overview report estimated that 533,000 people in Darfur have returned since the start of the conflict in 2003, including 209,200 people between January 2014 and December

2016. In Sudan, acute food insecurity is likely to persist in conflict-affected areas of Darfur 


\section{Global Proceedings Repository \\ American Research Foundation \\ ISSN 2476-017X}

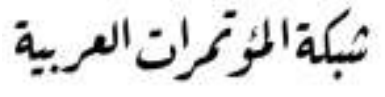

http://arab.kmshare.net/

Available online at http://proceedings.sriweb.org

states; in camps for IDPs, 1 in 10 people was found to be food insecure. The total population of IDPs living in camps is estimated at 1.6 million, with $4 \%$ being older adults (60+ years), $36 \%$ adults, and 60\% children (International Organization for Migration [IOM], 2016).

The crisis of food insecurity caused by displacement has been handled by humanitarian operations in Darfur. As explained in the World Food Programme (WFP) reports of 2011and 2016 , vulnerability levels are high within conflict-affected populations; as of 2017, an estimated 4.8 million IDPs are in need of humanitarian assistance. World Food Programme (WFP) reports

of 2016 and 2017 indicated that there was increase in food insecurity among IDPs as $48 \%$ of 'old' IDPs in Habila suffered from food insecurity in 2015 and 64\% in 2016. In Geneina, food insecurity among IDPs was at 29\% in 2015 and 42\% in 2016. In Habila, food consumption increased from $4 \%$ in 2015 to $28 \%$ in 2016 . In Geneina, food consumption increased from $5 \%$ in 2015 to $11 \%$ in 2016.

\section{The importance of the study:}

In 2016, the WFP in Sudan planned to assist 4.6 million affected people, of which 3.9 million reside in Sudan. As of June 2016 only 2.4 million of the people in need were reached. Therefore, about 1.5 million vulnerable of those who have been displaced are at some of the highest risks of facing food insecurity. Food insecurity doesn't only affect human health and welfare; it also contributes to economic vulnerability.

In West Darfur World Food Programme (WFP) with other humanitarians organizations play important role in providing humanitarian assistances for internal displaced people who affected 


\section{Global Proceedings Repository \\ American Research Foundation \\ ISSN 2476-017X}

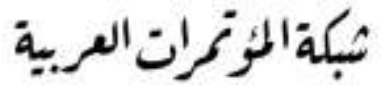

http://arab.kmshare.net/

Available online at http://proceedings.sriweb.org

by recurrent conflict, new and protracted displacement, regional insecurity, crisis levels malnutrition and food insecurity, chronic poverty and a deteriorating economy. IDP people have been suffering from their incapability to continue their planting and harvesting processes during agriculture seasons therefore, they left huge areas of lands uncultivated, further worsening the overall food security situation in both Geniena and Habila areas. Many trade routes are also unsecured due to conflict zones, therefore food delivery is also restricted. The security situation is risky in large parts of IDP's original villages in West Darfur, and it is a problem in general in reaching affected areas. IDPs specially women who are playing vital role in agriculture have also been afraid from being attacked by robbers. Thus, the conditions of vulnerability in which IDP, at all times, have lack physical, social and economic access to sufficient safe and nutritious food that meets their dietary needs and food preferences for an active and healthy life. The IDPs in Habila and Geniena are concerned about their access to land whether used for agriculture, cattle herding or as water resources . Land ownership is therefore often crucial to livelihood for IDPs pastoralists and agriculturalist communities and peasant societies, they need it in order to produce food and for grazing and watering their animals.

\section{Objectives of the study}

This main objective of this study was to identify the degree to which vulnerable 'old' IDPs rely on humanitarian food security assistance and sustainable development programmes in West Darfur (Geneina and Habila). Other objectives included the following: 


\section{Global Proceedings Repository \\ American Research Foundation \\ ISSN 2476-017X}

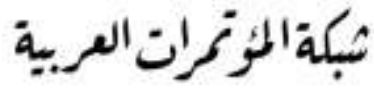

http://arab.kmshare.net/

Available online at http://proceedings.sriweb.org

1- To gain knowledge of the socio-economic characteristics of 'old' IDPs and their families.

2- To explore food insecurity causes and the food security strategies adapted by the 'old' IDPs in the two camps of Geneina and Habila

3- To increase our understanding of the socio-economic conditions of the IDP old people (60+ years) at the Geneina and Habila camps in terms of income, land and animal ownership systems, and the social protection system.

4- To identify social development services and facilities related to water, health, education and social insurance.

\section{Questions of the study}

1- What are the socio-economic characteristics of 'old' IDPs and their families in the two camps of Geneina and Habila?

2- What are the causes of food insecurity among 'old' IDPs in the two camps of Geneina and Habila and the strategies they use to adapt themselves?

3- What are the most socio-economic conditions increasing the state of vulnerability among the IDP old people (60+ years) at the Geneina and Habila camps in terms of income, land and animal ownership systems, and the social protection system.

4- What are the social development services and facilities related to water, health, education available to the IDP people at the Geneina and Habila camps.

The hypotheses: 


\section{Global Proceedings Repository \\ American Research Foundation \\ ISSN 2476-017X}

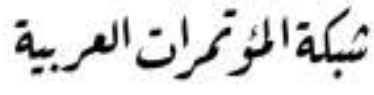

http://arab.kmshare.net/

Available online at http://proceedings.sriweb.org

1- Vulnerable 'old' IDPs in the study areas Geneina and Habila rely on humanitarian food security assistance.

2- Vulnerable 'old' IDPs in the study areas rely on sustainable development programs.

3- Vulnerable 'old' IDPs in the study areas get access to means of social inclusion and the social protection documents related to water, health, education and social insurance.

4- The 'old' IDPs' perceived reasons for returning back to their original villages in terms of unsafe conditions, land and animal ownership systems, and the social protection system.

\section{Terminology:}

1- West Darfur: West Darfur is a state in the Darfur region of Sudan. According to the $5^{\text {th }}$ Sudan Population and Housing Census (2008), the total population of West Darfur was reported as $1,308,225$ by enumeration; $1,504,770$ by birth; and 1,305,082 by permanent residence.

2- Vulnerability: Vulnerability refers to a combination of social, economic, and physical criteria, such as those who are socially isolated, dependents, of limited mobility or completely immobilized, employment, housing and food security. HelpAge International (HAI) Report 2006 identified social measures for vulnerability including: loss of role as the head of a large family, loss of status in the community, and loss of the ability to make a tangible contribution to the community. All of these are major criteria for identifying vulnerability.

3- Older people: The United Nations (UN) defines older people as those aged 60 years and above, and oldest-old refers to people who are over 80 years of age. (United Nations, 2013). 


\section{Global Proceedings Repository \\ American Research Foundation}

ISSN 2476-017X

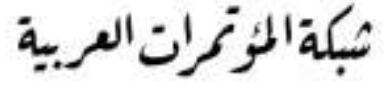

http://arab.kmshare.net/

Available online at http://proceedings.sriweb.org

This study uses the term 'old' IDPs to refer to people aged 60 years and above. And defines them in terms of what they have achieved in life, their wealth, knowledge that one has of important events, within different cultures based on their triable origin and their occupational line among IDPs, and change in physical appearance; health problems and physical work may change one's physical appearance; a lifetime's exposure to health problems and hard physical work may manifest itself through physical signs of aging.

4- Internally Displaced Persons: The United Nations (1998) defines IDPs as groups of persons who have been forced or obliged to flee or to leave their homes or places of habitual residence, and who have not crossed an internationally recognized state border. In this study, we add to the UN definition that IDPs are also those who remain at high risk of physical attack and are deprived of shelter, food and health services

5- Resilience: United Nations International Strategy for Disaster Reduction (UNISDR) defines resilience as the ability of a system, community, or society exposed to hazards to resist, absorb, accommodate, and recover from the effects of a hazard in a timely and efficient manner (UNISDR, 2009). The present study defines resilience as the ability of IDPs to recover from a shock (e.g. an act of violence) and the degree to which an IDP has the necessary resources to meet basic needs as well as his or her capability to organise him or herself both prior to and during times of need.

6- Food Security: The definition of food security was drawn up in the Report of the World Food Summit (1996) explained food security in terms of getting access to physical and 


\section{Global Proceedings Repository \\ American Research Foundation \\ ISSN 2476-017X}

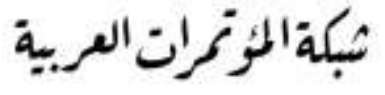

http://arab.kmshare.net/

economic sufficient, safe, and nutritious food that meet the dietary needs . (Food and Agriculture Organization, 1996). The present study defines food security as a situation where IDPs have availability, access, proper utilization, and stability of food over a certain time period.

7- Humanitarian Assistance: Humanitarian Assistance refers to the aid that seeks to save lives and alleviate suffering of a crisis affected population. It must be provided in accordance with the basic principles of humanity, impartiality, and neutrality. According to OCHA 2009, humanitarian assistance includes direct assistance, indirect assistance, and infrastructure support (OCHA, 2009). The present study defines humanitarian assistance as aid that intends to save the IDPs' lives; alleviate their suffering; maintain their dignity as humans during and after crises; and to strengthen preparedness when such situations occur, while upholding the humanitarian principles of humanity, impartiality, neutrality, and independence.

8- Sustainable Development: Sustainability measures whether an activity or an impact is likely to continue after donor funding has been withdrawn. According to (OECD,1999) sustainable development is a connectedness to the need to assure that activities related to short-term emergency situations are carried out in a context which takes longer-term and interconnected problems into account. Brundtland Report (WCED, 1987) embodies two key concepts: the role of social and economic development in meeting the needs of people, and the recognition that environmental capacities are limited, and if overused and degraded, will compromise our ability to meet future needs. Sustainable development is a process that meets the practical needs of IDPs and empowers them to meet their own future needs. Successful 


\section{Global Proceedings Repository \\ American Research Foundation}

ISSN 2476-017X

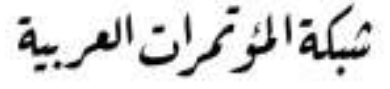

http://arab.kmshare.net/

Available online at http://proceedings.sriweb.org

sustainable development requires a basis of socio-cultural development, economic growth, political stability, and ecosystem protection, which are also important for disaster risk reduction that contributes to more sustainable development.

9- Social Development: According to the United Nations, social development is defined in terms of poverty eradication, employment generation, and social harmony (UN, 1996). Bilance (1997) defined that "Social Development is the promotion of a sustainable society that is worthy of human dignity by empowering marginalized groups, women and men, to undertake their own development, to improve their social and economic position and to acquire their rightful place in society. The above definition emphasizes an inclusive development that addresses the differential needs and aspiration of the diverse section of population. Social development thus implies the change in social institutions. Progress toward an inclusive society, for example, implies that individuals treat each other (more) fairly in their daily lives, whether in the family, workplace, or in public office (ISS, 2010). The Human Development Reports of United Nations Development Programme (UNDP) developed the Human Development Index (HDI), Human Poverty Index (HPI), and Genderrelated Development Index (GDI) (UNDP, 2000). The present study defines social development in terms of an IDPs' longevity, knowledge, standard of living, income, educational level, and economic provisioning for increased access to health services and safe water, while taking into consideration inequality between women and men. Additionally, social development means empowering IDPs to explore food insecurity causes, the root 


\section{Global Proceedings Repository \\ American Research Foundation}

ISSN 2476-017X

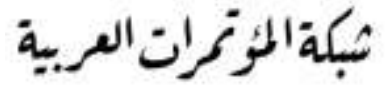

http://arab.kmshare.net/

Available online at http://proceedings.sriweb.org

causes of displacement and their impact on older IDPs, and empowering IDPs to confront such situations in the future.

\section{Literature review:}

One study explored the impact of Internally Displaced Persons on the tree cover at El Geniena in West Darfur. The objectives were to investigate the negative impact of IDPs on the vegetation cover and to assess the level of destruction of the vegetation cover due to IDPs' reliance on it for provisions. Primary and secondary data methods were used. The findings revealed that there were changes in the economic activities of the IDPs who lost their sources of income, mainly farming and private business; trading of forest products (fuel wood, charcoal, and building materials) became the source of income for the IDPs and this was reflected in an alarming deforestation trend (Abuelgasim, 2010).

The 2011 WFP report provided a comprehensive food security assessment in North, South, and West Darfur. The objectives were to provide a reliable assessment of the food security and vulnerability situation, and the causes of food insecurity and vulnerability. The West Darfur sample consisted of 1,100 households selected randomly and interviewed, using a household survey questionnaire designed to measure food security indicators. The findings about West Darfur showed $23 \%$ of households were food insecure, $33 \%$ of households were vulnerable to food insecurity, and $40 \%$ were food secure. In total, 322,000 people were food insecure and 504,000 people were vulnerable to food insecurity (WFP, 2011). 


\section{Global Proceedings Repository \\ American Research Foundation \\ ISSN 2476-017X}

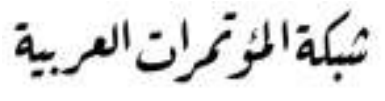

http://arab.kmshare.net/

Available online at http://proceedings.sriweb.org

Another study examined the effects of the Darfur conflicts on the dynamics of pastoralists' social status and livelihood options in Central and West Darfur states. Questionnaires were administered to households and a checklist for key criteria was used. The results showed that $75 \%$ of the pastoralists were working for themselves or for their families, $16 \%$ of them were working for others as labourers, and $9 \%$ of the community members were working for both themselves and other families. Before the conflict the communities were stable and there were sufficient number of pastoral labourers, when the conflict occurred people fled their villages and pastoral labourers number decreased. Twenty six percent of pastoral livelihood groups were pastoralist, $52 \%$ of the groups were agro-pastoralist, $19 \%$ of them were farmers, and 3\% of them were IDPs (Dawoud and Hassan, 2015).

The WFP Food Security Monitoring Report $\left(2016^{\mathrm{a}}\right)$ aimed to assess and provide reliable data on food security and the vulnerability situation of the West Darfur population, as well as identifying vulnerability for future planning. The results indicated that food security and household consumption deteriorated compared to resident communities at the same time in the previous year. These results were attributed to having limited access to cultivation and livelihood options. One-third of households in resident communities showed poor food consumption compared to over half of all IDP households surveyed.

\section{Theoretical framework:}




\section{Global Proceedings Repository \\ American Research Foundation \\ ISSN 2476-017X}

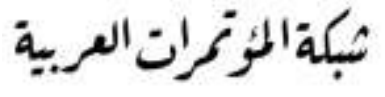

http://arab.kmshare.net/

Available online at http://proceedings.sriweb.org

Human Needs Theory was used as a theoretical framework for the present study. Coate and Rosati (1988), indicated that human needs are a key motivational force behind human behaviour and social interaction. Accordingly, there exist specific and relatively long-term human needs which individuals will strive to satisfy, even at the cost of personal disorientation and social disruption. It is important that these basic human needs are satisfied; if one is deprived of these needs, especially in the early years of development, he or she may suffer physically and psychologically. Maslow (1973 ) Hierarchy of Needs is also considered in this study.

He believes that human beings are motivated to behave in a certain way by stimuli and reinforcements (behaviourism). The hierarchy of needs consists of five levels of needs. The satisfaction of the basic needs at the lower level leads to the needs satisfaction at the upper levels, and so on. Maslow (1973) views some needs as more urgent than others, and more powerful too. In his opinion, these powerful needs are subsistence needs such as food, water, and shelter which he claims precede all other human needs. John Burton (1990) mentioned that the need for identity, recognition, security within the social identity group and other such human societal values are important for avoiding conflict. Also important are the need for participation and understanding (Kök, 2007). Institutions and policies are required to enable the fulfilment of these needs, and the unavailability of alternative means to meet the needs of individuals or groups is what triggers tension and violence. As Coate \& Rosati (1988) recommended, "social systems must be responsive to individual needs if they are to maintain their legitimacy and survive intact in the long run”.( Coate \& Rosati ,1988pp157). 


\section{Global Proceedings Repository \\ American Research Foundation \\ ISSN 2476-017X}

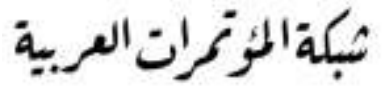

http://arab.kmshare.net/

Available online at http://proceedings.sriweb.org

\section{Methods:}

This study is based on scientific descriptive and thematic analytical approaches to analysing 'old' IDPs vulnerability to food insecurity, using quantitative and qualitative participatory tools of data collection. Quantitative tools included a questionnaire and interview check list. Focus group discussions were used as a qualitative tool, serving as a triangulation method to enhance data quality. Additionally, review and descriptive analysis of secondary data, such as studies and reports from international organizations, were performed. The questionnaire was verified by highly qualified specialized consultants of Food Security and Livelihood, then verified and approved by the qualified technical staff of the Humanitarian Aid Commission (HAC), and verbal consents was obtained from the IDPs at grassroots level. The questionnaire was pretested with a group of 'old' IDPs at Geneina camps before it was administered in 2017 in an urban location (Geneina) and a rural area (Habila). Simple random sampling was used to select households within the Habila and Geneina camps. The appropriate sample size was determined based on available information about vulnerable IDPs, IDP returnees, host communities, and nomads. 


\section{The Analysis and the Results:}

This part represent the analysis using the statistical analysis SPSS and the results as indicated in the following:

1- Frequency tables and the Cross-table between the parts.

2- Analysis of hypotheses

3- The result of analysis

First: Frequency tables and the Cross-table between the parts

Table (1): The Distribution of the IDPs by Gender:

\begin{tabular}{|c|c|c|}
\hline Gender & Frequency & Percentage \\
\hline Male & 103 & 46.8 \\
\hline Female & 117 & 43.2 \\
\hline Total & 220 & 100 \\
\hline
\end{tabular}

Table (1) shows the percentage of male is $46.8 \%$ and female is $53.2 \%$ from population study. Table (2): The Distribution of the IDPs by Age:

\begin{tabular}{|l|l|l|}
\hline Age & Frequency & Percentage \\
\hline
\end{tabular}




\section{Global Proceedings Repository \\ American Research Foundation}

ISSN 2476-017X

Available online at http://proceedings.sriweb.org

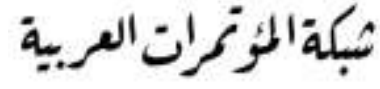

http://arab.kmshare.net/

\begin{tabular}{|c|c|c|}
\hline up 19 & 9 & 4.1 \\
\hline $20-29$ & 17 & 7.7 \\
\hline $30-39$ & 21 & 9.5 \\
\hline $40-49$ & 44 & 20.0 \\
\hline $50-59$ & 48 & 21.8 \\
\hline $60-69$ & 51 & 23.2 \\
\hline $70-79$ & 8 & 3.6 \\
\hline $80+$ & 22 & 10.0 \\
\hline Total & 220 & 100.0 \\
\hline
\end{tabular}

Table (2) shows the percentage of they age up to 19 is $4.1 \%$, age between (20-29) is7.7\%, age between (30-39) is 9.5\%, and show also Percentage age between (40-49) is 20.\%, age (50-59) is 12.8 , age between (60-69) is $23.2 \%$, age between (70-79) is $3.6 \%$ and age above than (80+) is $10 \%$ of the IDPs .

Table (3): Distribution of the of IDPs by Area:

\begin{tabular}{|c|c|c|}
\hline Area & Frequency & Percentage \\
\hline Geneina & 120 & 54.5 \\
\hline Habila & 100 & 45.5 \\
\hline total & 220 & 100.0 \\
\hline
\end{tabular}

Table (3) shows the percentage of the distribution of the IDPs of the two camps is $54.5 \%$ for Geneina and $45.5 \%$ for Habila.

Table (4): Distribution of the of IDPs by Educational Level:

\begin{tabular}{|c|c|c|}
\hline Education & Frequency & Percentage \\
\hline Primary & 17 & 7.7 \\
\hline Intermediate & 3 & 1.4 \\
\hline
\end{tabular}




\section{Global Proceedings Repository \\ American Research Foundation}

ISSN 2476-017X

Available online at http://proceedings.sriweb.org

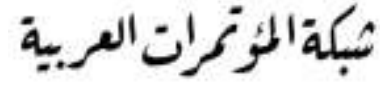

http://arab.kmshare.net/

\begin{tabular}{|c|c|c|}
\hline Secondary & 5 & 2.3 \\
\hline University & 2 & .9 \\
\hline Khalwa & 83 & 37.7 \\
\hline $\begin{array}{c}\text { No school / } \\
\text { Khalwa }\end{array}$ & 110 & 50.0 \\
\hline Total & 220 & 100.0 \\
\hline
\end{tabular}

Table (4) shows the percentage of the IDPs educational levels as for primary school is (7.7\%), (1.4\%) Intermediate school, (2.3\%) Secondary school, (0.9\%) University, (37.7\%) Khalwa and No school / Khalwa is (50\%) of population study.

Table (5): Distribution of the of IDPs by Household Occupations:

\begin{tabular}{|c|c|c|}
\hline Household & Frequency & Percentage \\
\hline Farming & 123 & 55.9 \\
\hline Pastoralist & 6 & 2.7 \\
\hline Agro-pastoralist & 12 & 5.5 \\
\hline Labour & 12 & 5.5 \\
\hline Trader & 41 & 18.6 \\
\hline Govt. employed & 14 & 6.4 \\
\hline
\end{tabular}




\section{Global Proceedings Repository \\ American Research Foundation}

ISSN 2476-017X

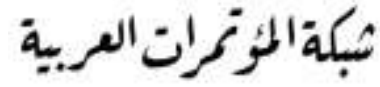

http://arab.kmshare.net/

Available online at http://proceedings.sriweb.org

\begin{tabular}{|c|c|c|}
\hline Unemployed & 12 & 5.5 \\
\hline Total & 220 & 100.0 \\
\hline
\end{tabular}

Table (5) shows the distribution of the IDPs by household occupations as (55.9\%) of sample is in Farming, (2.7\%) is Pastoralist, (5.5\%) is Agro-pastoralist, (5.5\%) is Labour, (18.6\%) is Trader, $(6.4 \%)$ is Govt. employed and (5.5\%) is Unemployed.

Table (6): chi-square test for Different Settlement Types in Habila and Geneina:

\begin{tabular}{|c|c|c|c|c|c|}
\hline \multirow{2}{*}{ Settlement } & \multicolumn{2}{|c|}{ Area } & \multirow[b]{2}{*}{ Total } & \multirow{2}{*}{$\begin{array}{c}\text { chi- } \\
\text { square }\end{array}$} & \multirow[b]{2}{*}{ SIG } \\
\hline & Geneina & Habila & & & \\
\hline IDPs & 81 & 26 & 107 & \multirow{5}{*}{47.122} & \multirow{5}{*}{0.00} \\
\hline Returnees & 3 & 20 & 23 & & \\
\hline Nomads & 0 & 6 & 6 & & \\
\hline Residents & 36 & 48 & 84 & & \\
\hline Total & 120 & 100 & 220 & & \\
\hline
\end{tabular}

Table (6) shows the Chi-Square test independent for Different Settlement Types and Area.

The calculated value Chi-Square is (47.12) and significant value is (0.00) less than (0.05) hence the two variables are dependent, that means there is no relationship between Different Settlement Types and Area.

Table (7): chi-square test for IDPs' Marital Status and Area:

\begin{tabular}{|c|c|c|c|c|c|}
\hline \multirow{2}{*}{ Status } & \multicolumn{2}{|c|}{ Area } & \multirow{2}{*}{ Total } & chi- & \multirow{2}{*}{ SIG } \\
\cline { 2 - 4 } & Geneina & Habila & & square & \\
\hline Married & 13 & 16 & 29 & 2.819 & 0.589 \\
\hline Widow & 11 & 17 & 28 & & \\
\hline
\end{tabular}




\section{Global Proceedings Repository \\ American Research Foundation}

ISSN 2476-017X

Available online at http://proceedings.sriweb.org

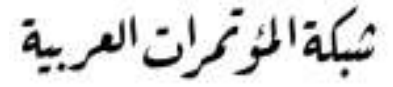

http://arab.kmshare.net/

\begin{tabular}{|c|c|c|c|}
\hline Divorced & 5 & 5 & 10 \\
\hline Separated & 1 & 5 & 6 \\
\hline Single & 2 & 6 & 8 \\
\hline Total & 32 & 49 & 81 \\
\hline
\end{tabular}

Table (7) shows the Chi-Square test independent for Marital Status of 'Old' IDPs Age 60-80+ and area. The calculated value Chi-Square (2.819) and significant value (0.589) greater than (0.05) hence the two variables are independent, that means there is relationship between Marital Status of 'Old' IDPs Age 60-80+ and Area.

Table (8): chi-square test for Respondents in Geneina and Habila by the Educational Level:

\begin{tabular}{|c|c|c|c|c|c|}
\hline \multirow{2}{*}{ Education } & \multicolumn{2}{|c|}{ Area } & \multirow{2}{*}{ Total } & $\begin{array}{c}\text { chi- } \\
\text { square }\end{array}$ & SIG \\
\cline { 2 - 4 } & Geneina & Habila & & & \\
\hline Primary & 12 & 5 & 17 & & \multirow{2}{*}{0.00} \\
\hline Intermediate & 3 & 0 & 3 & & \\
\hline Secondary & 5 & 0 & 5 & \\
\hline University & 1 & 1 & 2 & \\
\hline Khalwa & 72 & 11 & 83 & & \\
\hline No school / Khalwa & 27 & 83 & 110 & & \\
\hline Total & 120 & 100 & 220 & & \\
\hline
\end{tabular}

Table (8) shows the Chi-Square test independent level Education and area. The calculated value Chi-Square (83.091) and significant value (0.00) less than (0.05) hence the two variables are dependent, that means there is no relationship between the level of Education and area.

Table (9): chi-square test for Head of Household Occupations 


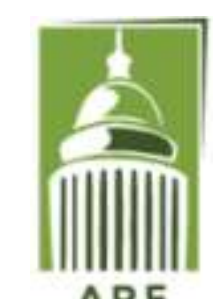

ARF

\section{Global Proceedings Repository \\ American Research Foundation}

ISSN 2476-017X

Available online at http://proceedings.sriweb.org

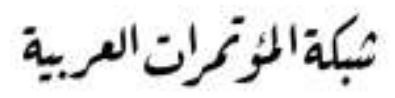

http://arab.kmshare.net/

\begin{tabular}{|c|c|c|c|c|c|}
\hline \multirow{2}{*}{ Household } & \multicolumn{2}{|c|}{ Area } & \multirow{2}{*}{ Total } & $\begin{array}{c}\text { chi- } \\
\text { square }\end{array}$ & \multirow{2}{*}{ SIG } \\
\cline { 2 - 4 } & Geneina & Habila & & \\
\hline Farming & 62 & 61 & 123 & & \\
\hline Pastoralist & 6 & 0 & 6 & \multirow{2}{*}{0.002} \\
\hline Agro-pastoralist & 7 & 5 & 12 & \\
\hline Labour & 3 & 9 & 12 & \\
\hline Trader & 30 & 11 & 41 & \\
\hline Govt. employed & 4 & 10 & 14 & & \\
\hline Unemployed & 8 & 4 & 12 & & \\
\hline Total & 120 & 100 & 220 & & \\
\hline
\end{tabular}

Table (9) shows the Chi-Square test independent for Household Occupations and Area. The calculated value is Chi-Square (20.402) and significant value is (0.002) less than (0.05) hence the two variables are dependent, that means there is no relationship between the Household Occupations and the Area.

Table (10): chi-square test for Respondents by Occupation

\begin{tabular}{|c|c|c|c|c|c|c|c|c|c|c|}
\hline \multirow[b]{2}{*}{ age } & \multicolumn{7}{|c|}{ Household } & \multirow[b]{2}{*}{ Total } & \multirow[b]{2}{*}{$\begin{array}{c}\text { chi- } \\
\text { square }\end{array}$} & \multirow[b]{2}{*}{ SIG } \\
\hline & Farming & Pastoralist & $\begin{array}{c}\text { Agro- } \\
\text { pastoralist }\end{array}$ & Labour & Trader & $\begin{array}{c}\text { Govt. } \\
\text { employed }\end{array}$ & $\begin{array}{c}\text { Unemp } \\
\text { loyed }\end{array}$ & & & \\
\hline up 19 & 1 & 0 & 2 & 3 & 3 & 0 & 0 & 9 & \multirow{8}{*}{227.75} & \multirow{8}{*}{0.0} \\
\hline $20-29$ & 2 & 0 & 3 & 6 & 3 & 0 & 3 & 17 & & \\
\hline $30-39$ & 21 & 0 & 0 & 0 & 0 & 0 & 0 & 21 & & \\
\hline $40-49$ & 37 & 0 & 0 & 0 & 7 & 0 & 0 & 44 & & \\
\hline $50-59$ & 28 & 0 & 0 & 0 & 19 & 0 & 1 & 48 & & \\
\hline $60-69$ & 24 & 6 & 7 & 3 & 0 & 4 & 7 & 51 & & \\
\hline $70-79$ & 4 & 0 & 0 & 0 & 4 & 0 & 0 & 8 & & \\
\hline $80+$ & 6 & 0 & 0 & 0 & 5 & 10 & 1 & 22 & & \\
\hline
\end{tabular}




\section{Global Proceedings Repository \\ American Research Foundation}

ISSN 2476-017X

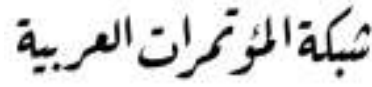

http://arab.kmshare.net/

Available online at http://proceedings.sriweb.org

\begin{tabular}{|l|l|l|l|l|l|l|l|l|l|}
\hline Total & 123 & 6 & 12 & 12 & 41 & 14 & 12 & 220 & \\
\hline
\end{tabular}

Table (10) shows the Chi-Square test independent for Household Occupation and Age. The calculated value Chi-Square is (227.754) and significant value is (0.000) less than (0.05) hence the two variables are dependent, that means there is no relationship between the Household Occupation and Age.

Table (11):chi-square test for land Types by Village

\begin{tabular}{|c|c|c|c|c|c|}
\hline \multirow{2}{*}{ Land } & \multicolumn{2}{|c|}{ Area } & \multirow{2}{*}{ Total } & $\begin{array}{c}\text { chi- } \\
\text { square }\end{array}$ & \multirow{2}{*}{ SIG } \\
\cline { 2 - 4 } & Geneina & Habila & & \\
\hline Goz & 31 & 33 & 64 & & \\
\hline Wadi & 29 & 38 & 67 & \multirow{2}{*}{10.454} & \multirow{2}{*}{0.015} \\
\hline Other & 3 & 2 & 5 & & \\
\hline NA & 57 & 27 & 84 & & \\
\hline Total & 120 & 100 & 220 & & \\
\hline
\end{tabular}

Table (11) shows that Chi-Square test independent land Types and area. The calculated value Chi-Square is (10.454) and significant value is (0.015) less than (0.05) hence that the two variables are dependent, that means there is no relationship between land Types and Area. Table (12): chi-square test for Factors Contributing to Low Productivity:

\begin{tabular}{|c|c|c|c|c|c|}
\hline & \multicolumn{2}{|c|}{ Area } & \multirow{2}{*}{ Total } & $\begin{array}{c}\text { chi- } \\
\text { square }\end{array}$ & SIG \\
\cline { 2 - 4 } & Geneina & Habila & & & \\
\hline Water & 0 & 28 & 28 & & \multirow{2}{*}{182.67} \\
\hline Inputs & 108 & 0 & 108 & 0.00 \\
\hline Practices & 0 & 14 & 14 & \\
\hline Low security & 12 & 38 & 50 & & \\
\hline Other & 0 & 20 & 20 & &
\end{tabular}




\section{Global Proceedings Repository \\ American Research Foundation}

ISSN 2476-017X

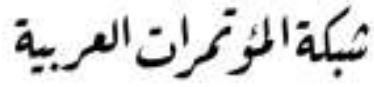

http://arab.kmshare.net/

Available online at http://proceedings.sriweb.org

\begin{tabular}{|l|l|l|l|} 
Total & 120 & 100 & 220 \\
\hline
\end{tabular}

Table (12) shows that Chi-Square test independent Factors Contributing to Low Productivity and area. The calculated value Chi-Square is (182.67) and significant value is (0.000) less than (0.05) hence that the two variables are dependent, that means there is no relationship between Factors Contributing to Low Productivity and Area.

Table (13): chi-square test for Food Shortage Coping Strategies and Age:

\begin{tabular}{|c|c|c|c|c|c|c|c|c|c|c|c|}
\hline & \multicolumn{8}{|c|}{ Age } & \multirow{2}{*}{ Total } & \multirow{2}{*}{$\begin{array}{c}\text { chi- } \\
\text { square }\end{array}$} & \multirow{2}{*}{ SIG } \\
\hline & up 19 & $20-29$ & $30-39$ & $40-49$ & $50-59$ & $60-69$ & $70-79$ & $80+$ & & & \\
\hline Market & 0 & 0 & 0 & 28 & 24 & 27 & 4 & 6 & 89 & \multirow{7}{*}{257.9} & \multirow{7}{*}{0.00} \\
\hline Kinship & 4 & 3 & 21 & 8 & 0 & 0 & 0 & 12 & 48 & & \\
\hline $\begin{array}{l}\text { Labour } \\
\text { for food }\end{array}$ & 5 & 9 & 0 & 1 & 2 & 24 & 0 & 0 & 41 & & \\
\hline Wild food & 0 & 4 & 0 & 7 & 13 & 0 & 0 & 0 & 24 & & \\
\hline Food aid & 0 & 0 & 0 & 0 & 6 & 0 & 2 & 4 & 12 & & \\
\hline Other & 0 & 1 & 0 & 0 & 3 & 0 & 2 & 0 & 6 & & \\
\hline Total & 9 & 17 & 21 & 44 & 48 & 51 & 8 & 22 & 220 & & \\
\hline
\end{tabular}

Table (13) shows the Chi-Square test independent Food Shortage And age. The calculated value Chi-Square is (257.9) and significant value is (0.000) less than (0.05) hence that the two variables are dependent, that means there is no relationship between Food Shortage and Age. Table (14): chi-square test for Food Shortage Coping Strategies and Area:

\begin{tabular}{|c|c|c|c|c|c|}
\hline & \multicolumn{2}{|c|}{ Area } & \multirow{2}{*}{ Total } & \multirow{2}{*}{ chi-square } & \multirow{2}{*}{ SIG } \\
\cline { 2 - 4 } & Geneina & Habila & & & \\
\hline Market & 29 & 60 & 89 & 34.9 & 0.00 \\
\hline Kinship & 36 & 12 & 48 & & \\
\hline
\end{tabular}




\section{Global Proceedings Repository \\ American Research Foundation}

ISSN 2476-017X

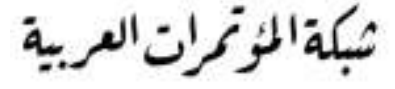

http://arab.kmshare.net/

Available online at http://proceedings.sriweb.org

\begin{tabular}{|c|c|c|c|}
\hline Labour for food & 26 & 15 & 41 \\
\hline Wild food & 20 & 4 & 24 \\
\hline Food aid & 6 & 6 & 12 \\
\hline Other & 3 & 3 & 6 \\
\hline Total & 120 & 100 & 220 \\
\hline
\end{tabular}

Table (14) shows that Chi-Square test independent Food Shortage Coping Strategies and Area.

The calculated value Chi-Square is (34.9) and significant value is $(0.000)$ less than (0.05) hence that the two variables are dependent, that means there is no relationship between Food Shortage and Area.

Table (15): chi-square test for Access to Animal Vaccination

\begin{tabular}{|c|c|c|c|c|c|}
\hline \multirow{2}{*}{ Animal } & \multicolumn{2}{|c|}{ Area } & \multirow{2}{*}{ Total } & \multirow{2}{*}{ chi-square } & SIG \\
\cline { 2 - 4 } & Geneina & Habila & & & \\
\hline Yes & 4 & 6 & 10 & & \multirow{2}{*}{0.894} \\
\hline No & 116 & 94 & 210 & 0.344 \\
\hline Total & 120 & 100 & 220 & & \\
\hline
\end{tabular}

Table (15) shows that Chi-Square test independent Animal Vaccination and Area. The calculated value Chi-Square is (0.894) and significant value is (0.344) greater than (0.05) hence that the two variables are independent, that means there is relationship between Animal Vaccination and Area.

Table (16): chi-square test for Factors Preventing from Raising Animals:

\begin{tabular}{|c|c|c|c|c|c|}
\hline & \multicolumn{2}{|c|}{ Area } & \multirow{2}{*}{ Total } & \multirow{2}{*}{ chi-square } & \multirow{2}{*}{ SIG } \\
\cline { 2 - 4 } & Geneina & Habila & & & \\
\hline Lack of pasture & 46 & 36 & 82 & 0.209 & \multirow{2}{*}{0.976} \\
\hline Unsafe conditions & 32 & 28 & 60 & & \\
\hline
\end{tabular}




\section{Global Proceedings Repository \\ American Research Foundation}

ISSN 2476-017X

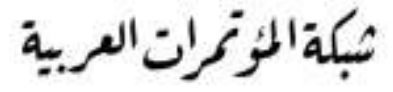

http://arab.kmshare.net/

Available online at http://proceedings.sriweb.org

\begin{tabular}{|c|c|c|c|}
\hline Lack of water for livestock & 22 & 20 & 42 \\
\hline Lack of veterinary services & 20 & 16 & 36 \\
\hline Total & 120 & 100 & 220 \\
\hline
\end{tabular}

Table (16) shows the Chi-Square test independent Factors Preventing from Raising Animals and Area. The calculated value Chi-Square is (0.209) and significant value is (0.976) greater than (0.05) hence that the two variables are independent, that means there is relationship between Factors Preventing from Raising Animals and Area.

Table (17): chi-square test for Access to Means of Social Inclusion

\begin{tabular}{|c|c|c|c|c|c|}
\hline \multirow{2}{*}{ Means } & \multicolumn{2}{|c|}{ Area } & \multirow{2}{*}{ Total } & \multirow{2}{*}{ chi-square } & \multirow[b]{2}{*}{ SIG } \\
\hline & Geneina & Habila & & & \\
\hline Legal documentation & 6 & 8 & 14 & \multirow{8}{*}{56.595} & \multirow{8}{*}{0.00} \\
\hline Access to social services & 10 & 11 & 21 & & \\
\hline National health insurance & 0 & 1 & 1 & & \\
\hline Security insurance & 8 & 22 & 30 & & \\
\hline Community work & 5 & 29 & 34 & & \\
\hline Support from other NGOs & 2 & 2 & 4 & & \\
\hline NA & 89 & 27 & 116 & & \\
\hline Total & 120 & 100 & 220 & & \\
\hline
\end{tabular}




\section{Global Proceedings Repository \\ American Research Foundation}

ISSN 2476-017X

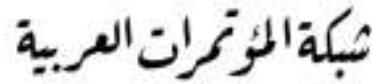

http://arab.kmshare.net/

Available online at http://proceedings.sriweb.org

Table (17) shows the Chi-Square test independent Social Inclusion and Area. The calculated value Chi-Square is (56.595) and significant value is (0.00) less than (0.05) hence the two variables are dependent, that means there is no relationship between Social Inclusion and Area. Table (18): Food Insecurity among Old IDPs of Geneina and Habila Camps:

\begin{tabular}{|l|c|c|c|c|c|}
\hline \multirow{2}{*}{ Area } & \multirow{2}{*}{ Year } & \multicolumn{2}{|c|}{ Food Security } & \multicolumn{2}{c|}{ Food consumption } \\
\cline { 3 - 6 } & & $\begin{array}{c}\text { Food } \\
\text { insecure }\end{array}$ & $\begin{array}{c}\text { Food } \\
\text { secure }\end{array}$ & Poor & Acceptable \\
\hline IDPs: Habila & 2015 & $48 \%$ & $15 \%$ & $4 \%$ & $38 \%$ \\
\cline { 2 - 6 } & 2016 & $64 \%$ & $11 \%$ & $28 \%$ & $27 \%$ \\
\hline IDPs Geneina: & 2015 & $29 \%$ & $21 \%$ & $5 \%$ & $59 \%$ \\
\cline { 2 - 6 } & 2016 & $42 \%$ & $27 \%$ & $11 \%$ & $47 \%$ \\
\hline
\end{tabular}

Source: WFP 2015 and 2016 Reports

Table(18) shows comparison between food Security (Food insecure, Food secure) and Food consumption (Poor, Acceptable) it was observed that there is in increase percentage of food insecure in Geneina and Habila around the two years, and food secure decrease in Habila while increase in Geneina between the two years 2015-2016. Acceptable decreased in both Habila and Geneina by $(11 \%)$ and $(12 \%)$ respectively.

\section{Second: the Analysis of the hypotheses}

\begin{tabular}{|c|c|c|c|c|c|}
\hline $\begin{array}{c}\text { First } \\
\text { hypothesis }\end{array}$ & $\mathrm{N}$ & weight Mean & Std. Deviation & Ch-square & Sig \\
\hline Result & 220 & 2.27 & 1.374 & 125.327 & 0.00 \\
\hline
\end{tabular}

Analysis of the first hypothesis (Vulnerable 'old' IDPs in the study areas Geneina and Habila rely on humanitarian food security assistance.) the study found that the weight mean is equal to (2.27), standard deviation is (1.374), chi- Square value is (125.327), sig value is (0.00) less than $(0.05)$ hence the null hypotheses it will be rejected. 


\section{Global Proceedings Repository \\ American Research Foundation}

ISSN 2476-017X

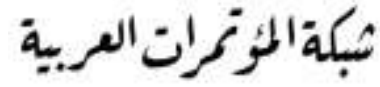

http://arab.kmshare.net/

Available online at http://proceedings.sriweb.org

\begin{tabular}{|c|c|c|c|c|c|}
\hline $\begin{array}{c}\text { Second } \\
\text { hypothesis }\end{array}$ & N & weight Mean & Std. Deviation & Ch-square & Sig \\
\hline Result & 220 & 5.39 & 2.007 & 294.373 & 0.00 \\
\hline
\end{tabular}

Analysis of the Second hypothesis (Vulnerable 'old' IDPs in the study areas rely on sustainable development programs.) the study found that the weight mean is equal to (5.39), standard deviation is (2.007), chi- Square value is (294.373), sig value is (0.00) less than (0.05) hence the null hypotheses will be rejected.

\begin{tabular}{|c|c|c|c|c|c|}
\hline $\begin{array}{c}\text { Three } \\
\text { hypothesis }\end{array}$ & $\mathrm{N}$ & weight Mean & Std. Deviation & Chi-square & Sig \\
\hline Result & 220 & 5.2409 & 1.22797 & 184.091 & 0.00 \\
\hline
\end{tabular}

Analysis of the third hypothesis (Vulnerable 'old' IDPs in the study areas get access to means of social inclusion and the social protection documents related to water, health, education and social insurance.) at the Geneina and Habila camps in terms of income, land and animal ownership systems, and the social protection system.) the study found the weight mean is equal to (5.2409), standard deviation is (1.22797), chi- Square value is (184.091), sig value is (0.00) less than (0.05) hence the null hypotheses it will be rejected.

\begin{tabular}{|c|c|c|c|c|c|}
\hline $\begin{array}{c}\text { Fourth } \\
\text { hypothesis }\end{array}$ & $\mathrm{N}$ & weight Mean & Std. Deviation & Chi-square & Sig \\
\hline Result & 220 & 5.37 & 2.027 & 293.418 & 0.00 \\
\hline
\end{tabular}




\section{Global Proceedings Repository \\ American Research Foundation}

ISSN 2476-017X

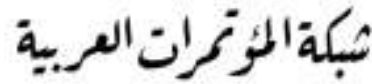

http://arab.kmshare.net/

Available online at http://proceedings.sriweb.org

Analysis of the fourth hypothesis (The 'old' IDPs' perceived reasons for returning back to their original villages in terms of unsafe conditions, land and animal ownership systems, and the social protection system.) the study found that the weight mean is equal to (5.37), standard deviation is (2.027), chi- Square value is (293.418), sig value is (0.00) less than (0.05) hence the null hypotheses it will be rejected.

\section{Third: the Analysis Result}

The study found that:

1- The percentage of male is $42.6 \%$ and female is $48.3 \%$ of the study sample.

2- The higher percentage for age of the sample whose age between (60-69) is $21.1 \%$ and lower percentage of the sample whose age about (70-79) is $3.3 \%$..

3- The higher percentage for educational level of sample is (50\%) for no school/ khalwa and lower one of the sample is (1.4\%) for primary school.

4- The higher percentage of the Household Occupations is (55.9\%) of sample in Farming and lower percentage of the sample is $(2.7 \%)$ for Pastoralist.

5- The comparison between food Security (Food insecure, Food secure) and Food consumption (Poor, Acceptable) it was observed that there was increase in the percentage of food insecure in Geneina and Habila around the two years 20 15-2016, Also food secure acceptable decreased in both Habila and Geneina by (11\%) and (12\%) respectively.

6- The Chi-Square test independent for Different Settlement Types and Area the study found that there is no relationship between Different Settlement Types and Area.

7- The Chi-Square test independent for Marital Status of 'Old' IDPs Age 60-80+ and area have relationship between Marital Status of 'Old' IDPs Age 60-80+ and Area.

8- The Chi-Square test independent level Education and Area, the study found that there is no relationship between the level of Education and Area. 


\section{Global Proceedings Repository \\ American Research Foundation \\ ISSN 2476-017X}

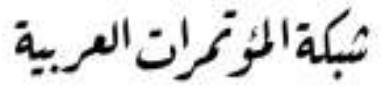

http://arab.kmshare.net/

Available online at http://proceedings.sriweb.org

9- The Chi-Square test independent for Household Occupations and area, the study found that there is no relationship between Household Occupations and Area.

10- The Chi-Square test independent for Household Occupation and age, the study found that there is no relationship between the Household Occupation and Age.

11- The Chi-Square test independent for land Types and area the study found that there is no relationship between land Types and Area.

12- The Chi-Square test independent for Factors Contributing to Low Productivity and Area the study found that there is no relationship between for Factors Contributing to Low Productivity and area.

13- The Chi-Square test independent for Food Shortage and Age the study found that there is no relationship between for Food Shortage and Age.

14- The Chi-Square test independent for Food Shortage and Area the study found that there is no relationship between for Food Shortage and Area.

15- The Chi-Square test independent for Animal Vaccination and Area the study found that there is relationship between for Animal Vaccination and Area.

16- The Chi-Square test independent for Factors Preventing from Raising Animals and Area the study found that there is relationship between for Factors Preventing from Raising Animals and Are.

17- The Chi-Square test independent for independent Social Inclusion and Area the study found that there is no relationship between Social Inclusion and Area.

18- The Analysis of the hypothesis (Vulnerable 'old' IDPs in the study areas Geneina and Habila rely on humanitarian food security assistance.) the study found sig value is $(0.00)$ less than (0.05) hence the null hypothesis it will be rejected.

19- The Analysis of the hypothesis (Vulnerable 'old' IDPs in the study areas rely on sustainable development programs) the study found that sig value is (0.00) less than (0.05) hence the null hypothesis will be rejected. 


\section{Global Proceedings Repository \\ American Research Foundation \\ ISSN 2476-017X}

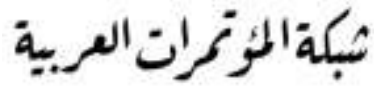

http://arab.kmshare.net/

Available online at http://proceedings.sriweb.org

20- The Analysis of the hypothesis (Vulnerable 'old' IDPs in the study areas get access to means of social inclusion and the social protection documents related to water, health, education and social insurance.) the study found that the sig value is (0.00) less than (0.05) hence the null hypothesis will be rejected.

21- The Analysis of the hypothesis (The 'old' IDPs' perceived reasons for returning back to their original villages in terms of unsafe conditions, land and animal ownership systems, and the social protection system.) the study found that the sig value is (0.00) less than (0.05) hence the null hypothesis will be rejected.

\section{Recommendations:}

To fully reintegrate back the returnees into their previous socio-economic life a participatory approaches should be given a high priority in all phases of the sustainable social development programmes including planning, implementations and management of their community development activities. This require full coordination between all stockholders involved in these social sustainable development programmes. Empowerment of the returnees and building their capacity on who to plan and manage their sustainable activities is an important issue in this process of reintegration.

Women's felt needs especially the widows and separated women needs to be reflected in all sustainable development activities. Social sustainable development programmes priorities should be directed to lasting peace situation, provision of the appropriate livelihood programmes, land ownership based on land tenure system, provision of social services mainly health, education, water and social protection. Provision of equal agriculture; animal husbandry and other economic opportunities should be given high 


\section{Global Proceedings Repository \\ American Research Foundation}

ISSN 2476-017X

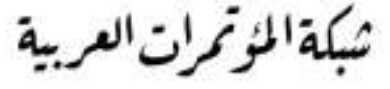

http://arab.kmshare.net/

Available online at http://proceedings.sriweb.org

priorities in the reintegration processes to alleviate food shortages and reduce market food purchasing. Also consideration of the ecological system and environmental protection lead to the sustainability of social development activities.

\section{References:}

Abuelgasim, M. (2010). MS Thesis, Impact of internal displaced persons on the tree cover at El Geniena locality, West Darfur State - Sudan, University of Upper Nile.

Bilance, (1997). "A world in balance - Bilance stands for Social Development: Policy paper". Cited in 'Social Development' retrieved from ISS (2010). Indices of Social Development. International Institute of Social Studies.

Revisiting the Prospects of Social Entrepreneurship on Social Development: An Analysis (PDF Download Available). Available from:

https://www.researchgate.net/publication/308803998 Revisiting the Prospects of Social Entreprene urship on Social Development An Analysis [accessed Dec 15 2017].

Burton, J. (1987) Resolving Deep-Rooted Conflict: A Handbook, Lanham, MD, University Press of America.

Burton, J. (1990) Conflict: Resolution and prevention. New York: St. Martin's Press.

Central Bureau of Statistics Sudan (2008) $5^{\text {th }}$ Sudan Population and Housing Census, 2008.

Central Bureau of Statistics Sudan.

Coate, R. A. and Rosati, J. A. (eds) (1988) The Power of Human Needs in World Society, Boulder, CO: Lynne Rienner Publishers. 


\section{Global Proceedings Repository \\ American Research Foundation \\ ISSN 2476-017X}

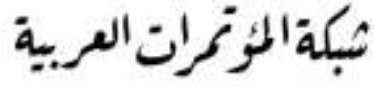

http://arab.kmshare.net/

Available online at http://proceedings.sriweb.org

Dawoud, A. A. and Hassan, T. A. (2015). 'The dynamics of pastoralist livelihoods in central and West Darfur states as a result of Darfur conflict', Journal of Agricultural Science and Engineering, 1 (2), pp. 83-88.

Famine Early Warning System Network (FEWSNET ) (2015). 'Sudan food security outlook report: January 2015 to June 2015 ', available online at $h t t p: / / w w w . f e w s . n e t / e a s t-$ africa/sudan/food-security-outlook/january-2015.

Famine Early Warning System Network (FEWSNET ) (2016). 'Sudan food security outlook report: October 2016, available online at

http://www.fews.net/sites/default/files/documents/reports/SD_OL_2016_10_final.pdf

Food and Agriculture Organization of the United Nations (FAO) (1996). 'Rome declaration on world food security and world food summit plan of action', available online at http://www.fao.org/docrep/003/w3613e/w3613e00.htm.

HelpAge International Report .(2006). Rebuilding Lives in Longer Term Emergencies, Older

People Experience in Darfur.

International Organization for Migration .(IOM) (2016). 'Annual report for 2016', available online at $h$ ttps://governingbodies.iom.int/system/files/en/council/108/C-1084\%20\%20Annual\%20Report\%20for\%202016.pdf.

Kök, H. (2007). 'Reducing violence: Applying the human needs theory to the conflict', Review of International Law and Politics, 3(11), pp. 89-108.

Maslow, A. H. (1973) The Farther Reaches of Human Nature, Harmondworth: Penguin Books. 


\section{Global Proceedings Repository \\ American Research Foundation \\ ISSN 2476-017X}

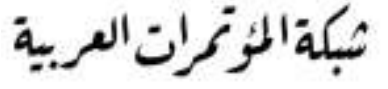

http://arab.kmshare.net/

Available online at http://proceedings.sriweb.org

Organisation for Economic Cooperation and Development(OECD).(1999). Guidance for

Evaluating Humanitarian Assistance in Complex Emergencies, OECD Publications, Parise,

France.

United Nations.(1996). Report of the World Summit for Social Development Copenhagen, 6-12

March 1995, New York, 1996. Available on line at

https://www.un.org/development/desa/dspd/world-summit-for-social-development-1995.html

United Nations Office for the Coordination of Humanitarian Affairs .(OCHA) .(2009). 'Darfur

humanitarian profile No. 34', available online at $h t t p s: / / r e l i e f w e b . i n t / s i t e s / r e l i e f w e b$ .intffiles/resources/D85EAF37950F12548525758B006DF908-Full_Report.pdf.

United Nations Department of Economic and Social Affairs (DESA), Population Division.

(2013). 'World population ageing', available online at http://www.un.org/en/development /desa/population/publications/pdf/ageing/WorldPopulationAgeing2013.pdf.

United Nations (UN) (1998) 'Addendum: Guiding principles on internal displacement', available online at $h t t p: / / w w w . u n-d o c u m e n t s . n e t / g p i d . h t m$.

United Nations (UN) (1995) The Copenhagen Declaration and Programme of Action: World Summit for Social Development, New York: United Nations.

United Nations Development Programme (UNDP) (1994) Human Development Report 1994, Oxford and New York: Oxford University Press.

United Nations Development Programme (UNDP) (2000) Human Development Report 2000, Oxford and New York: Oxford University Press. 


\section{Global Proceedings Repository \\ American Research Foundation \\ ISSN 2476-017X}

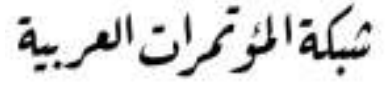

http://arab.kmshare.net/
ARF
Available online at http://proceedings.sriweb.org

United Nations International Strategy for Disaster Reduction (UNISDR) (2009) 2009 UNISDR

Terminology on Disaster Risk Reduction, Geneva, Switzerland: UNISDR.

World Commission on Environment and Development (WCED).(1987). Brundtland Report,

Oxford University Press, England

World Food Programme (WFP) (2016) 'Food security monitoring: West Darfur, Sudan, May

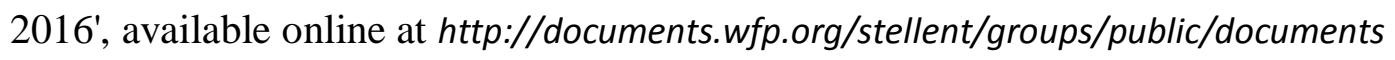

/ena/wfp284767.pdf. 